\title{
IN VITRO GENOTOXICITY OF WASTEWATERS FROM THE TOWN OF SETTAT, MOROCCO
}

\author{
Jaouad EL ASSLOUJ ${ }^{1}$, Loubna AMAHDAR ${ }^{2}$, Kamal GLOUIB ${ }^{2}$, Sanae KHOLTEI ${ }^{1}$, \\ Namira EL AMRANI PAAZA ${ }^{3}$, Luc VERSCHAEVE ${ }^{4}$, and Abderraouf HILALI ${ }^{2}$ \\ Laboratory of Environmental Metrologyl, Research Group on Toxicogenetics and Mutagenesis, Laboratory \\ of Agrofood and Health2 , Laboratory of Applied Geology', University Hassan I, FST Settat, Morocco, \\ Scientific Institute of Public Health, Department of Epidemiology and Toxicology, Brussels, Belgium ${ }^{4}$
}

Received in October 2008

Accepted in March 2009

\begin{abstract}
In recent years, the town of Settat has seen a considerable industrial growth, which has resulted in increased environmental pollution. This includes pollution by household and industrial wastewaters, which are released into the Boumoussa River without any preliminary treatment. The river valley crosses the community of Mzamza $8 \mathrm{~km}$ to the north of the town. Years of drought forced members of the community to use this polluted ground water for irrigation and put themselves and the environment at risk.

The aim of this study was to determine the physicochemical and metal profile of Settat wastewaters and to assess their impact on the water table. The second objective was to investigate the genotoxic potential of wastewater on human peripheral blood lymphocytes in vitro, using the micronucleus test and cellular proliferation index.

This study demonstrated significant pollution of Boumoussa valley groundwater and of the local wells. Sampled water induced a clear increase in the frequency of micronucleated cells and a lower cell proliferation in human peripheral blood lymphocytes in vitro.
\end{abstract}

KEY WORDS: Boumoussa, heavy metals, micronuclei, physicochemical profile, proliferation index

In Morocco, wastewaters generated by various economic activities are used for many applications. However, their use for irrigation poses an enormous threat to the environment and humans. Nevertheless, this is exactly what is being done near the town of Settat, located in the heart of Morocco, $70 \mathrm{~km}$ to the south of Casablanca. In recent years, this town has underwent a considerable industrial growth, and household and industrial wastewaters have been released in the Boumoussa River without any preliminary treatment. The river valley has become an open sewer. It crosses the community of Mzamza $8 \mathrm{~km}$ to the north of the town (zone of study). The plateau of Settat is characterised by a semi arid climate. The temperature is about $20^{\circ} \mathrm{C}$ on average, and precipitation is about $400 \mathrm{~mm}$ a year (1). This plateau has a very important water potential, and is the only water resource for the community of Mzamza (2). Years of drought, however, have forced members of the community to use this water for irrigation and to put themselves and the environment at risk posed by contaminated groundwater.

We determined the physicochemical profile and the content of heavy metals $(\mathrm{Pb}, \mathrm{Al}, \mathrm{Zn}, \mathrm{Cd}$ and $\mathrm{Cr}$ ) of the wastewater and water of the wells located in the vicinity of the Boumoussa valley. We also studied in vitro the genotoxic effects of this water on human peripheral blood lymphocytes using the micronucleus test and calculating the cell proliferation index. 


\section{MATERIALS AND METHODS}

\section{Study area}

We studied the area of household and industrial wastewater discharge from the town of Settat. We sampled wastewaters and water from wells located in the Boumoussa valley and its vicinity (Figure 1, Table 1). Sampling station B was somewhat distant from the Boumoussa valley (Figure 1) and sampling included household and industrial wastewater as well as rainwater leaving the main drain. Station $\mathrm{C}$ was located in the Boumoussa valley, at a little distance

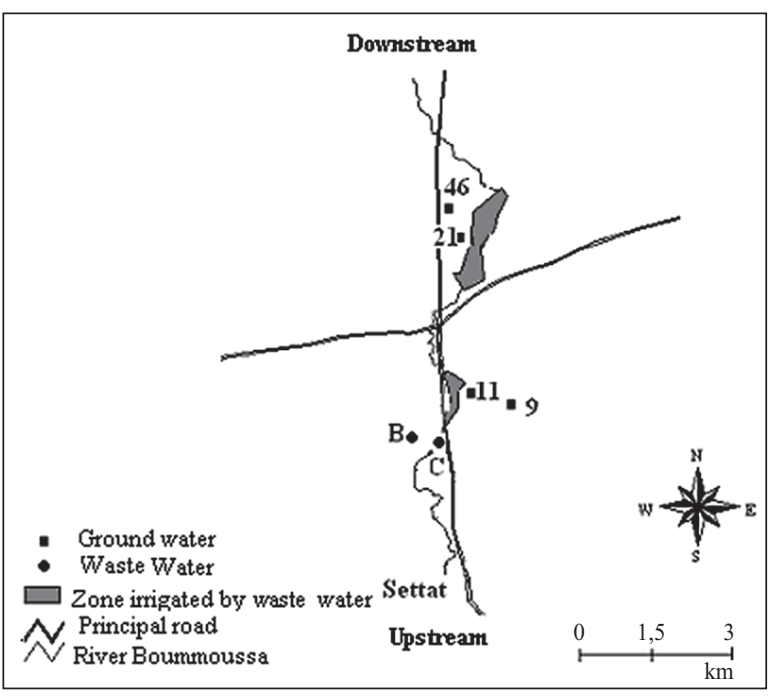

Figure 1 Geographic location of the sample sites from the confluence. The wells that were included in this study were designated as wells $9,11,21$, and 46. Well 9 was distant from the Boumoussa valley, whereas wells 11,21 , and 46 were near the valley.

\section{Water analysis}

Waste and well water were collected in polyethylene bottles and transported in portable refrigerators at $4{ }^{\circ} \mathrm{C}$. Physicochemical profiling was based on the AFNOR 2001 (3) and Rodier 1996 (4) standards. For heavy metal analysis, we mineralised waste and well water using nitric, hydrochloric, and perchloric acid (Merck, supra pure quality). Chromium, aluminium, lead, zinc, and cadmium content were measured using inductively coupled plasma atomic emission spectroscopy (ICP-AES). Mercury was analysed using a mercury AMA254 analyser.

\section{Micronucleus test}

Blood was sampled in a sterile heparin test tube from a non-smoking healthy and sober 27-year-old man, who gave informed consent for participation in the study. Cell cultures were made according to the standard protocol for the micronucleus test as described by Fenech and Morley (5). Briefly, $0.5 \mathrm{~mL}$ of total venous blood was incubated in glass tubes containing $5 \mathrm{~mL}$ RPMI 1640 growth medium supplemented with $15 \%$ foetal calf serum (SigmaAldrich Chemie $\mathrm{GmbH}), 1 \%$ of phytohaemagglutinine CAS \#14930-96-2, Sigma-Aldrich Chemie GmbH),

Table 1 Water sampling locations and distance of the wells from pollution sources

\begin{tabular}{lccccc}
\hline Stations & Depth / $\mathbf{m}$ & Altitude / $\mathbf{m}$ & $\begin{array}{c}\text { Distance to } \\
\text { sources of } \\
\text { pollution } / \mathbf{m}\end{array}$ & Observations & Type of irrigation \\
\hline 9 & 24.0 & 310 & 1150 & Unprotected & Irrigation by rain water \\
11 & 19.0 & 400 & Unprotected & Irrigation by rain water \\
21 & 18.1 & 273 & 475 & Unprotected & Irrigation by waste water \\
46 & 11.9 & 500 & 500 & Unprotected & Irrigation by waste water
\end{tabular}

Waste water B Domestic and industrial waste water as well as rain water leaving the mean drain. At some distance from the Boumoussa Riveer

Waste water C A mix of waste water B and the water of the Boumoussa River 
and $1 \%$ penicilline/streptomycine (Sigma-Aldrich Chemie $\mathrm{GmbH}$ ). Culture tubes were incubated in the presence of $50 \mu \mathrm{L}, 100 \mu \mathrm{L}, 200 \mu \mathrm{L}$, or $400 \mu \mathrm{L}$ of tap water, wastewater, or well water. Tap water was used as negative control, since it is the most consumed drinking water. The tubes were then placed horizontally in an incubator at $37^{\circ} \mathrm{C}$. Cytochalasin-B (CAS \#9008-97-3, Sigma-Aldrich Chemie GmbH) was added after 44 hours $(0.1 \mathrm{~mL}$ per tube to achieve the concentration of $3 \mu \mathrm{g} \mathrm{mL}^{-1}$ in culture). At $72 \mathrm{~h}$ of incubation, cell suspensions were centrifuged at $1000 \mathrm{rpm}$ for 10 minutes and subjected to a hypotonic shock with $0.075 \mathrm{~mol} \mathrm{~L}^{-1} \mathrm{KCl}$. The cells were then fixed with a 1:3 acetic acid : methanol solution and spread over clean microscope slides. The slides were air-dried, stained with $5 \%$ Giemsa in phosphate buffer $(\mathrm{pH}=6.8)$ and coded. Each slide was examined for the presence of micronuclei (MN) using a light microscope (400X and 1000X). For MN identification we used the criteria as described by Fenech and Morley (5). Altogether, 1000 cells per treatment were scored and the code was broken only after all readings were performed.

\section{Proliferation index}

Cell proliferation index (PI) is an indirect measurement of cell cycle duration, and is calculated according to the following formula

$$
\mathrm{PI}=\frac{\left(1 \times \mathrm{N}_{1}\right)+\left(2 \times \mathrm{N}_{2}\right)+\left(3 \times \mathrm{N}_{3}\right)+\left(4 \times \mathrm{N}_{4}\right)}{1000 \text { cells analysed }}
$$

where $N_{1}$ to $N_{4}$ is the number of cells with 1 to 4 nuclei (6).

\section{Statistical analysis}

The statistically significant difference between control and treated samples was determined using the ANOVA II test without repetition.

\section{RESULTS AND DISCUSSION}

\section{Physicochemical and metal profiling}

Table 2 gives a brief physicochemical profile of control, waste, and well water. Wastewater collected at the point of discharge or at the Boumoussa valley had very low dissolved oxygen levels, not exceeding $9 \%$. Well water had dissolved oxygen below the standard limits (except for well 9). Water from stations B and $\mathrm{C}$ also had $1.466 \mathrm{mg} \mathrm{L}^{-1}$ and $1.379 \mathrm{mg} \mathrm{L}^{-1}$ of nitrite ioins, respectively and $105 \mathrm{mg} \mathrm{L}^{-1}$ and $84.6 \mathrm{mg} \mathrm{L}^{-1}$ of ammonium, which are usually of household origin. Nitrates exceeded or approached the standard levels in all well waters except in well 9 , which is the most

Table 2 Physicochemical profile of waste and well

\begin{tabular}{|c|c|c|c|c|c|c|c|c|c|}
\hline Stations & $\begin{array}{c}\text { Water } \\
\text { level*/ } \mathrm{m}\end{array}$ & $\begin{array}{c}\mathrm{PO}_{4} / \\
\mathrm{mg} \mathrm{L}^{-1}\end{array}$ & pH & $\begin{array}{c}\mathrm{Cl} / \\
\mathrm{mg} \mathrm{L}^{-1}\end{array}$ & $\begin{array}{c}\text { Conductivity } \\
\text { at } 20^{\circ} \mathrm{C} / \\
\mu \mathrm{S} \mathrm{cm}^{-1}\end{array}$ & $\begin{array}{c}\mathrm{NO}_{3} / \\
\mathrm{mg} \mathrm{L}^{-1}\end{array}$ & $\begin{array}{c}\mathrm{NO}_{2} / \\
\mathrm{mg} \mathrm{L}^{-1}\end{array}$ & $\begin{array}{l}\mathrm{NH}_{4} / \\
\mathrm{g} \mathrm{L}^{-1}\end{array}$ & $\mathrm{O}_{2} / \%$ \\
\hline B & 0 & 4.020 & 9.65 & 1065 & 2385.32 & 10.09 & 1.466 & 105 & 6.40 \\
\hline $\mathrm{C}$ & 0 & 3.544 & 9.59 & 894.6 & 2285.71 & 17.07 & 1.379 & 84.6 & 9.00 \\
\hline 21 & 4.78 & 0.041 & 7.72 & 1065 & 3505.15 & 92.63 & 0.046 & 0.02 & 59.5 \\
\hline 46 & 4.00 & 0.044 & 7.28 & 795.2 & 3265.31 & 90.10 & 0.041 & 0.02 & 52.0 \\
\hline 11 & 17.80 & 0.009 & 7.62 & 881.4 & 2857.14 & 47.33 & 0.017 & 0.03 & 53.7 \\
\hline 9 & 19.21 & 0.009 & 7.06 & 463.0 & 1616.16 & 8.920 & 0.008 & 0.003 & 77.4 \\
\hline Tap water & 0 & 0 & 7.08 & 433.0 & 1100.00 & 10.55 & 0 & 0 & 76.0 \\
\hline $\begin{array}{l}\text { Moroccan } \\
\text { standards } \\
(2002)\end{array}$ & ---- & 0.700 & $\begin{array}{c}6.50 \text { to } \\
8.50\end{array}$ & 750.0 & 2700.00 & 50.00 & 0.100 & 0.50 & 70.0 \\
\hline $\begin{array}{l}\text { WHO } \\
\text { standards } \\
(1996)\end{array}$ & ----- & ---- & $\begin{array}{c}6.50 \text { to } \\
8.50\end{array}$ & 250.0 & 1200.00 & 50.00 & 3.000 & --- & 75.0 \\
\hline
\end{tabular}

* compared to the ground 
distant from the Boumoussa valley. At stations B and $\mathrm{C}$ nitrate concentrations were above standard $(50 \mathrm{mg}$ $\left.\mathrm{L}^{-1}\right)$. Lower nitrate concentrations at other places are most probably due to reduction by organic matter (7).

At wells 21,46 , and 11 conductivity was higher than the Moroccan standard (8) and higher than conductivity measured for wastewater. This is probably due to the presence of carbonated rocks in contact with ground waters (9). Except for well 9 water, chlorides exceeded the national standard.

Orthophosphates in wastewater were of household origin and were related to faeces and detergents (10). The observed values of $4.02 \mathrm{mg} \mathrm{L}^{-1}$ and $3.54 \mathrm{mg} \mathrm{L}^{-1}$ at points $\mathrm{B}$ and $\mathrm{C}$, respectively are considerably higher than the values for well and tap water.

Groundwater $\mathrm{pH}$ was neutral to slightly alkaline, with a maximum of 7.72, whereas wastewater $\mathrm{pH}$ was alkaline, with a maximum of 9.65 at station B.

Wastewaters taken at stations $\mathrm{B}$ and $\mathrm{C}$ had $\mathrm{Pb}, \mathrm{Cr}$, $\mathrm{Cd}, \mathrm{Al}, \mathrm{Zn}$ and $\mathrm{Hg}$ levels considerably higher than those observed in well and tap water (Table 3). Except for $\mathrm{Cd}$ and $\mathrm{Hg}$, all other levels were higher than the Moroccan and WHO (11) standards. It is important to point out that wastewater from stations $\mathrm{B}$ and $\mathrm{C}$ contained particularly high concentrations of $\mathrm{Al}, \mathrm{Zn}$, and $\mathrm{Pb}$. These high levels can be due to specific use of land due to important industrial activities in the area, those related to surface treatments in particular.

Heavy metal concentrations measured in well and tap water were markedly lower than the Moroccan or WHO standards, and all well water concentrations were of the same order of magnitude as of tap water.

It should be noted that $\mathrm{Al}$ levels in wells 21,46 , and 11 approach the WHO limit. This may be related to

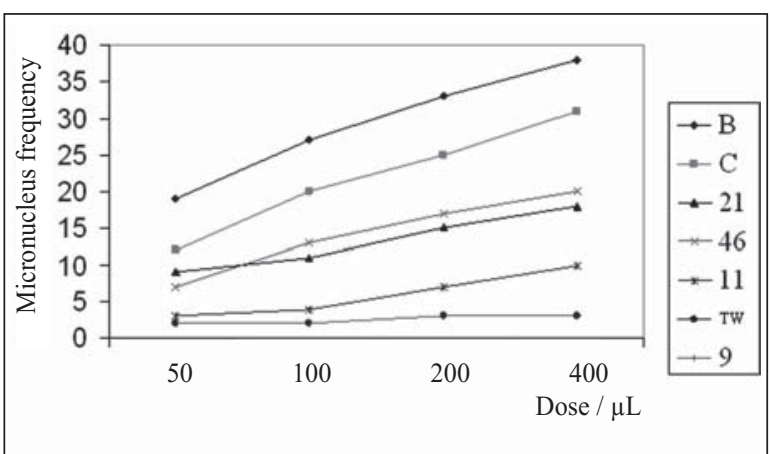

Figure 2 Micronucleus frequency in human peripheral blood lymphocytes in relation to wastewater $(B, C)$, well water $(9,11,21,46)$, or tap water $(T W)$ doses $(\mu L)$ added to cell cultures its mobility which is greater than of other metals (12), and also to its natural occurrence as aluminosilicate, which is the major constituent of clay (13).

\section{Micronucleus test and proliferation index (PI)}

In this study, we used the micronucleus test to investigate the genotoxicity of the waste and well waters because it is a well-known and validated test system that was recently found to be predictive of cancer risk at the population level (14). This test detects chromosome breaks (clastogenicity) and aneuploidy (e.g. as a result of disturbances in the mitotic spindle). Furthermore, it can be more sensitive than the bacterial Ames assay, especially when heavy metal contamination is anticipated (15, 16). Recently, an inter-laboratory comparison study has also demonstrated that the in vitro micronucleus test is indeed very suitable for routine wastewater testing (17).

Data on micronucleus frequency are given in Figure 2 and Table 4. The frequencies of micronucleated cells increased with the amount of water added to cultures. However, this dose-related increase was statistically significant only for the wells 46 and 21 $(p<0.05)$. When the micronucleus frequencies were compared between control (tap water) and exposed cultures (waste and well water), statistically significant increases were found for both stations and wells 21 and 46. Micronucleus frequency in the control culture was 3 micronuclei per 1000 binucleated cells, which is in accordance with literature and our own historical data $(5,18)$. This frequency (and an absence of the doseeffect relationship) was also found for well 9 water, which was the most distant from the Boumoussa valley (both graph lines on Figure 2 are overlapping).

Wells 21 and 46 showed the most significant effect among the wells, which is probably due to their vicinity to stations $\mathrm{B}$ and $\mathrm{C}$ and likely infiltration of pollutants from these wastewaters into the ground water.

Figure 3 and Table 4 show the proliferation index $(\mathrm{PI})$. A significant increase $(\mathrm{p}<0.05)$ was found in cells treated with water from wells 21 and 46 compared to control (tap water). The difference was highly significant between the $\mathrm{B}$ and $\mathrm{C}$ stations and the tap water $(p<0.001)$. With addition of more water PI would decrease, but not significantly. This dosedependent decrease in proliferation may be indicative of the toxic effect of pollutants in the samples. It is not due to addition of increased volumes of water, as this had already been ruled out by tests which showed 


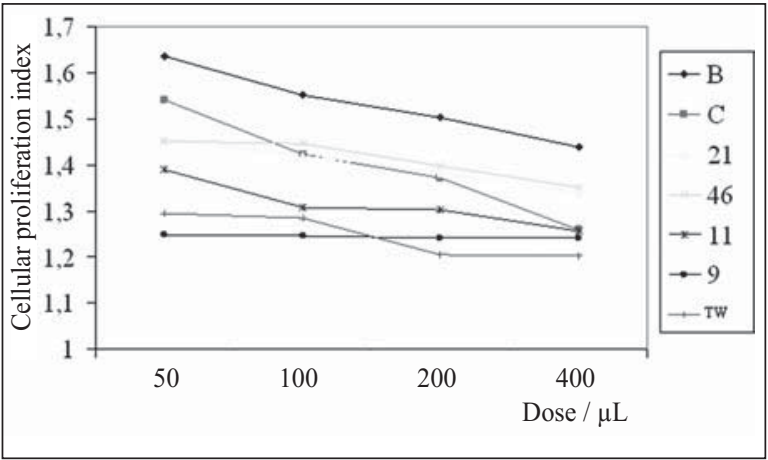

Figure 3 Peripheral blood lymphocyte proliferation index in relation to wastewater $(B, C)$, well water $(9,11$ $21,46)$, or tap water $(T W)$ doses $(\mu L)$ added to cell cultures

that adding volumes of up to $800 \mu \mathrm{L}$ did not influence cell cultures and did not induce a toxic response, e.g., as a result of changed osmolarity (19).

Our results clearly demonstrate a high pollution level of the wastewaters in the Boumoussa valley and adjacent wells, which in turn involves significantly higher genotoxicity. This finding is in accordance with earlier investigations. Among recently published studies, reference can be made to Durgo et al. (16) who investigated wastewater polluted by fertilisers from a phosphoric gypsum depot near a factory in Croatia. Using the alkaline comet assay, they found a significant DNA damaging potential of wastewater on human leukocytes, but no effect in the Ames test. Aleem and Malik (20) investigated untreated wastewater from industrial and household sources that is used to irrigate agricultural crops in Aligarh, India. Extracts from irrigated soils were tested with different bacterial test systems and found to be clearly genotoxic. The same was found for wastewater from the Indian city of Ghaziabad (21). Significant genotoxicity was also found with four different genotoxicity tests of untreated wastewater from different industries. It was also shown that genotoxicity could partially or completely be eliminated by wastewater treatment (22). Another example is a study by Swaileh et al. (23), who found genotoxicity in oat plants irrigated with wastewater. Of particular reference to our study is the study by Kholtei, who demonstrated a significant increase in DNA breaks in cells exposed to wastewater from the town of Settat (2). Other investigations have confirmed genotoxic effects in humans (18) and animals (24) who drank the Boumoussa water and showed elevated micronucleus frequencies in their white blood cells. So far, no follow up is available on the health status of the investigated animals and humans, but these studies clearly suggest that their health may be impaired in the long run.

Our and the above mentioned investigations made no attempt to determine whether elevated micronucleus frequencies were related to clastogenic and/or aneugenic effects of one or more pollutants. We also did not attempt to identify the compounds that were actually contributing to the observed genetic damage. Some of the heavy metals found in concentrations above limits, are the likely culprits such as lead, chrome, aluminium, and cadmium, as they may in certain forms be mutagenic. In general, metal genotoxicity is caused by indirect mechanisms, of which three are predominant (25): a) interference with cellular redox regulation and induction of oxidative stress, which may cause oxidative DNA damage [also see (26)]; b) inhibition of major DNA repair systems, resulting in genomic instability and accumulation of critical mutations [also see (26)]; and

Table 3 Heavy metals in wastewater $(B, C)$, well water $(9,11,21,46)$ or tap water samples

\begin{tabular}{lcccccc}
\hline \multirow{2}{*}{ Stations } & $\mathbf{P b}$ & $\mathbf{C r}$ & $\mathbf{C d}$ & $\mathbf{A l}$ & $\mathbf{Z n}$ & $\mathbf{H g}$ \\
\cline { 2 - 7 } & 4.7921 & 0.2622 & 0.0030 & 22.6815 & 5.8048 & 0.0336 \\
$\mathrm{~B}$ & 4.5356 & 0.2206 & 0.0025 & 22.2053 & 5.7504 & 0.0136 \\
$\mathrm{C}$ & 0.0156 & 0.0014 & 0.0009 & 0.0589 & 0.0429 & 0.0005 \\
21 & 0.0130 & 0.0016 & 0.0008 & 0.0458 & 0.0292 & 0.0001 \\
46 & 0.0036 & 0.0011 & 0.0001 & 0.0434 & 0.0129 & 0.0000 \\
11 & 0.0009 & 0.0004 & 0.0001 & 0.0120 & 0.0012 & 0.0000 \\
9 & 0.0030 & 0.0000 & 0.0000 & 0.0040 & 0.0021 & 0.0000 \\
Tap water & 0.0500 & 0.0500 & 0.0050 & 0.2000 & 5.0000 & 1.0000 \\
\hline Morrocan & & & & & & \\
standard & & & & & & \\
(2002) & & 0.0500 & 0.0030 & 0.0500 & & \\
WHO standard & 0.0100 & & & & & \\
(1996) & & & & & & \\
\hline
\end{tabular}


Table 4 Results of statistical analyses for micronucleus frequencies and proliferation index determined in human peripheral blood lymphocytes treated with wastewater $(B, C)$, well water $(9,11,21,46)$ or tap water in vitro

\begin{tabular}{lcccc}
\hline & \multicolumn{2}{c}{ Micronuclei } & \multicolumn{2}{c}{ Proliferation Index (PI) } \\
\cline { 2 - 5 } & $\mathbf{F}^{*}$ & Significance / & $\mathbf{F}^{*}$ & Significance / p \\
\hline Station B/C & 811.00 & $<0.001$ & 57.14 & $<0.05$ \\
Station B/ well 9 & 48.58 & $<0.001$ & 51.92 & $<0.05$ \\
Station B/ Well 11 & 78.39 & $<0.05$ & 188.11 & $<0.001$ \\
Station B/ Well 21 & 54.86 & $<0.05$ & 63.36 & $<0.05$ \\
Station B/ Well 46 & 135.00 & $<0.05$ & 31.16 & $<0.05$ \\
Station B/ Drinking Water & 48.58 & $<0.001$ & 164.20 & $<0.001$ \\
Station C/ Well 9 & 26.68 & $<0.0001$ & 7.33 & $\mathrm{NS}$ \\
Station C/ Well 11 & 39.38 & $<0.0001$ & 6.961 & $\mathrm{NS}$ \\
Station C/ Well 21 & 17.42 & $<0.05$ & 5.46 & $\mathrm{NS}$ \\
Station C/ Well 46 & 38.44 & $<0.05$ & 0.11 & $\mathrm{NS}$ \\
Station C/ Drinking Water & 26.68 & $<0.001$ & 14.91 & $<0.05$ \\
Well 9/ Well 11 & 7.00 & $\mathrm{NS}$ & 7.10 & $\mathrm{NS}$ \\
Well 9/ Well 21 & 37.73 & $<0.05$ & 42.41 & $<0.05$ \\
Well 9/ Well 46 & 21.04 & $<0.05$ & 59.26 & $<0.05$ \\
Well 11/ Well 21 & 229.36 & $<0.0001$ & 75.96 & $<0.001$ \\
Well 11/ Well 46 & 33.00 & $<0.05$ & 38.85 & $<0.05$ \\
Well 11/ Drinking Water & 7.00 & $\mathrm{NS}$ & 13.97 & $<0.05$ \\
Well 21/ Well 46 & 1.00 & $\mathrm{NS}$ & 3.83 & $\mathrm{NS}$ \\
Well 21/ Drinking Water & 37.73 & $<0.001$ & 212.36 & $<0.0001$ \\
Well 46/ Drinking Water & 21.04 & $<0.05$ & 278.40 & $<0.0001$ \\
\hline
\end{tabular}

*Compared with theoretical $F$ of 10.1279645

NS=statistically not significant

c) deregulation of cell proliferation by induction of signalling pathways or inactivation of growth controls such as tumour suppression genes. In addition, specific metal compounds exhibit unique mechanisms such as interruption of cell-cell adhesion by cadmium, direct DNA binding of trivalent chromium produced from hexavalent chromium [also see (27)], or perturbation of the mitotic spindle or inhibition of its formation. The latter holds true for $\mathrm{Cr}^{+6}$ products $\left(\mathrm{Na}_{2} \mathrm{CrO}_{4}\right.$ and $\left.\mathrm{CaCrO}_{4}\right)$ and aluminium chloride $(28,29)$.

It is important to investigate deeper into these mechanisms in the future. In the meantime, our and other studies demonstrate the importance of environmental monitoring and the need for water treatment stations in the afflicted areas.

\section{Acknowledgement}

This work was supported by INRA/CRDI (project number 100771-004).

\section{REFERENCES}

1. Ittas A. Urbanisation et assainissement: cas de la ville de Settat [Urbanization and sanitation: the case of the city of Settat; in French] [Thesis Management and Urbanism]. Rabat: 2001.

2. Kholtei S. Caractérisation physico-chimique des eaux usées de la ville de Settat et de Berrechid et évaluation de leur impact sur la qualité des eaux souterraines [physico-chemical characterization of waste waters from the towns of Settat and Berrechid and their impact on the ground water table; in French]. [PhD Thesis]. Casablanca: University Hassan I; 2002.

3. Association Française de Normalisation (AFNOR). Qualité de l'eau. Tome 1: Terminologie, échantillonnage et évaluation des méthodes [Water quality. Volume 1: Terminology, sampling and evaluation methods ; in French]. $6^{\text {th }}$ ed. Paris: AFNOR; 2001.

4. Rodier J, Bazin C, Broutin JP, Chambon P, Champsaur H, Rodi L, editors. L'analyse de l'eau: Eaux naturelles, eaux résiduaires, eaux de mer: chimie, physico-chimie, microbiologie, biologie, interprétation des résultats [Water analysis: natural waters, residual waters and sea waters : chemistry, physico-chemistry, microbiology, biology, interpretation of the results; in French]. $8^{\text {th }}$ ed. Paris: DUNOD; 1996. 
5. Fenech M, Morley AA. Measurement of micronuclei in lymphocytes. Mutat Res 1985;147:29-36.

6. Titenko-Holland N, Windhan G, Kolachana P, Reinish F, Paravatham S, Osorio AM. Genotoxicity of malathion in human lymphocytes assessed using the micronucleus assay in vitro and in vivo: a study of malathion-exposed workers. Mutat Res 1997;388:85-95.

7. Hassoune EM, Bouzidi A, Koulali Y, Hadarbach D. Effets des rejets liquides domestiques et industriels sur la qualité des eaux souterraines au nord de la ville de Settat (Maroc) [Effects of liquid domestic and industrial waste discharge on the groundwater quality at the north of the town of Settat (Morocco); in French]. Bull Inst Sci Rabat Sect Sci Vie 2006;28:61-71.

8. Moroccan Standard, 2002. Setting standards for drinking water for human consumption. Official Gazette No. 5062 of 30. Ramadan 1423 (5-12-2002).

9. El Bouqdaoui K. Geological and geotechnical study of the city of Settat. Mapping geotechnical and useful substances in the province of Settat. [PhD Thesis] Rabat: Faculty of Science, University Mohammed V; 1995.

10. Bontoux J.Introduction à l'étude des eaux douces, eaux naturelles, eaux usées, eaux de boisson [Introduction to the study of fresh water - natural waters, waste waters and drinking water, in French], Liège: Cebedoc; 1993.

11. World Health Organization (WHO). Guidelines for drinking water quality. Vol 2, Health and other supporting criteria. $2^{\text {nd }}$ ed. Geneva: WHO; 1996.

12. Fekhaoui M, Abouzaid H, Foutlane A. Study of metal contamination of sediments and algae from the Wadi Sebou subject to emissions from the city of Fez. Bull Inst Sci Rabat 1993;1:13-20.

13. Kholtei S, Bouzidi A, Bonin M, Fekhaoui M, Anan R, Sbai $\mathrm{K}$, Creppy EE. Contamination of groundwater in the plain of Berrechid in the region of Chaouia in Morocco by heavy metals in wastewater: effects of rainfall. Vect Environ 2003;36:68-80.

14. Bonassi S, Znaor A, Ceppi M, Lando C, Chang WP, Holland N, Kirsch-Volders M, Zeiger E, Ban S, Barale R, Bigatti MP, Bolognesi C, Cebulska-Wasilewska A, Fabianova E, Fucic A, Hagmar L, Joksic G, Martelli A, Migliore L, Mirkova E, Scarfi MR, Zijno A, Norppa H, Fenech M. An increased micronucleus frequency in peripheral blood lymphocytes predicts the risk of cancer in humans. Carcinogenesis 2007;28:625-31.

15. Lah N, Vidic T, Glasencnik E, Cepeljnik T, Gorjanc G, Marinsek-Logar R. Genotoxicity evaluation of water soil leachates by Ames test, comet assay, and preliminary Tradescantia micronucleus assay. Environ Monit Assess 2008;139:107-18.

16. Durgo K, Oreščanin V, Lulic̉ S, Kopjar N, Želježić D, Franekić Čolić J. The assessment of genotoxicity effects of wastewater from a fertilizer factory. J Appl Toxicol 2009;29:42-51.

17. Reifferscheid G, Ziemann C, Fieblinger D, Dill F, Gminski R, Grummt H-J, Hafner C, Hollert H, Kunz S, Rodrigo G, Stopper H, Selke D. Measurement of genotoxicity in wastewater samples with the in vitro micronucleus test - Results of a round-robin study in the context of standardisation according to ISO. Mutat Res 2008;649:1527.

18. Glouib K, Hilali A, El Kettani S, Verschaeve L. Cytogenetic biomonitoring of the Mzamza population exposed to untreated wastewaters. Bull Environ Contam Toxicol 2007;79:231-6.

19. Amahdar L, Anouar A, Ababou B, Verschaeve L, Hilali A. In vitro genotoxicity of Settat town landfill leachate, Morocco. Arh Hig Rada Toksikol 2009;60:179-84.

20. Aleem A, Malik A. Genotoxic hazards of long-term application of wastewater on agricultural soil. Mutat Res 2003;538:145-54

21. Ansari MI, Malik A. Genotoxicity of wastewater used for irrigation of food crops. Environ Toxicol 2009; 24:103-15.

22. Krishnamurthi K, Saravana Devi S, Hengstler JG, Hermes M, Kumar K, Dutta D, Muhil Vannan S, Subin TS, Yadav RR, Chakrabarti T. Genotoxicity of sludges, wastewater and effluents from three different industries. Arch Toxicol 2008;82:965-71.

23. Swaileh KM, Hussein R, Ezzughayyar A. Evaluating wastewater-induced plant genotoxicity using randomly amplified polymorphic DNA. Environ Toxicol 2009;23:11722. (DOI 10.1002/tox.20316)

24. Kadmiri I, Glouib K, Verschaeve L, and Hilali A. Cytogenetic monitoring of domestic mammals exposed to wastewaters from the localities of Dladla and Boukallou near Settat, Morocco. Environ Int 2006;32:690-6.

25. Beyersmann D, Hartwig A. Carcinogenic metal compounds: recent insight into molecular and cellular mechanisms. Arch Toxicol 2008;82:493-512.

26. Filipic M, Fatur T, Vudrag M. Molecular mechanisms of cadmium induced mutagenicity. Hum Exp Toxicol 2006;25:67-77.

27. Léonard A, Lauwerys RR. Carcinogenicity and mutagenicity of chromium. Mutat Res 1980;76:227-39.

28. Nijs M, Kirsch-Volders M. Induction of spindle inhibition and abnormal mitotic figures by $\mathrm{Cr}(\mathrm{II}), \mathrm{Cr}(\mathrm{III})$ and $\mathrm{Cr}(\mathrm{VI})$ ions. Mutagenesis 1986;1:247-52.

29. Lima PD, Leite DS, Vasconcellos MC, Cavalcanti BC, Santos RA, Costa-Lotufo LV, Pessoa C, Moraes MO, Burbano RR. Genotoxic effects of aluminium chloride in cultured human lymphocytes in different phases of the cell cycle. Food Chem Toxicol 2007;45:1154-9. 


\section{Sažetak}

\section{IN VITRO ISTRAŽIVANJE GENOTOKSIČNOG POTENCIJALA OTPADNIH VODA GRADA} SETTATA (MAROKO)

Nagli industrijski razvoj u gradu Settatu posljednjih je godina rezultirao povećanim onečišćenjem okoliša, osobito putem otpadnih voda iz kućanstava i industrije. Te se otpadne vode bez ikakve prethodne obrade odlažu u dolinu rijeke Boumoussa na području zajednice Mzamza, $8 \mathrm{~km}$ sjeverno od grada. Uzastopne sušne sezone lokalnoj su zajednici nametnule potrebu za uporabom tih voda za navodnjavanje, čime su i zajednica i okoliš postali izloženi povećanim rizicima od onečišćenja tla i izvora podzemnih voda.

Svrha ovog istraživanja bila je provesti fizikalno-kemijsku karakterizaciju i utvrđivanje sadržaja metala u otpadnim vodama grada Settata te procijeniti njihove učinke na gornji sloj podzemnih voda. Ujedno je istraživan genotoksični potencijal otpadnih voda u uvjetima in vitro na limfocitima periferne krvi čovjeka primjenom mikronukleusnog testa i proliferacijskog indeksa. Istraživanje je potvrdilo visok stupanj onečišćenja vodâ u dolini Boumoussa, kao i vodâ iz bunara smještenih u neposrednoj blizini. Štetni su učinci onečišćenja potvrđeni i na osnovi povišene učestalosti stanica s mikronukleusima te snižene vrijednosti proliferacijskog indeksa u limfocitima periferne krvi u uvjetima in vitro.

KLJUČNE RIJEČI: Boumoussa, fizikalno-kemijska karakterizacija, mikronukleus, proliferacijski indeks, teški metali

\section{CORRESPONDING AUTHOR:}

Professor Abderraouf Hilali

University Hassan I, Faculty of Sciences and Technics

Settat, Km 3, Route de Casablanca

B.P. 577,26000 Settat, Morocco

E-mail:Hilalia@hotmail.com 